\title{
Ocular findings in systemic lupus erythematosus
}

\author{
D. H. GOLD, D. A. MORRIS, AND P. HENKIND
}

From the Department of Ophthalmology, New York Medical Center, 550 First Avenue, New York, U.S.A.

25 years ago systemic lupus erythematosus was a relatively obscure entity. Much has since been published and lupus has achieved the status of a well-recognized and not uncommonly diagnosed condition. It is a multi-system disorder classified with the "collagen diseases", and its manifestations are protean. The joints, skin, kidneys, and cardiopulmonary system are most commonly affected. In addition, there may be involvement of the eye, blood, liver, spleen, bones, lymph nodes, nervous tissue, and gastrointestinal system (Dubois and Tuffanelli, r964; Larson, r96r). Though the precise aetiology is obscure, it appears that abnormal immunological processes play a part in its pathogenesis.

In the present study we report the results of ocular examinations in a series of 6 I patients with systemic lupus, and contrast our findings with those of a number of earlier series. We emphasize that the concept of a fairly high incidence of ocular manifestations in systemic lupus erythematosus is no longer valid. It was based on earlier studies in which patients were, for the most part, either not treated or inadequately treated by current standards. Today's patients, treated more successfully for systemic lupus, rarely present with ocular signs or symptoms.

\section{Material and methods}

The $6 \mathrm{I}$ patients ( $5 \mathrm{I}$ women and 10 men) were referred from the systemic lupus clinic of Bellevue Hospital, and were seen at a total of 270 visits (ranging from $r$ to to examinations per patient) by one of us (P.H.) over the past ro years. The diagnosis was confirmed by positive LE-cell preparations or, in a few cases, by antinuclear antibody studies. When these patients were seen, their disease was essentially under control. The majority had received or were receiving treatment with systemic antimalarial and/or steroid preparations. Ocular examination of each patient included visual acuity, slit-lamp biomicroscopy, ocular tension, fluorescein staining of the cornea, HRR colour testing, Amsler grid, and direct and indirect ophthalmoscopy.

\section{Findings}

The ocular findings are summarized in the Table (overleaf).

Corneal staining without a distinctive pattern was noted in four patients. In the only patient with possible uveitis, trace flare and cells were recorded at one visit and had cleared 2 days later without treatment. A solitary cotton-wool spot was found in one eye of two patients on one visit only. The spots were not observed on previous or subsequent visits. One of these patients was hypertensive and had arteriolar narrowing; the other was normotensive. No retinal haemorrhages were seen in this series, and a single patient (non-diabetic) had one microaneurysm in one eye. Seven patients were described as having arterio-venous crossing changes; of these, four were hypertensive. Of thirteen

Received for publication December 30, 1971

Address for reprints: Dr. P. Henkind, Department of Ophthalmology, Montefiore Hospital and Medical Center, 11 I East 2 Ioth Address for reprints: Dr. P. Henkin
Street, Bronx, New York, U.S.A.

This work was supported by Grant No. EY-00469 from the National Eye Institute. 
patients with arteriolar narrowing, nine had hypertension. One patient (with hypertension) had "hard" exudates in the fundus. No patient had oedema of the optic disc. Fifteen patients were hypertensive (diastolic pressures of $100 \mathrm{~mm}$. Hg or more). Macular pigmentary mottling was seen in 32 patients, thirty of whom had received or were receiving oral chloroquine or hydroxychloroquine; four of these thirty were considered to have definite, advanced, chloroquine retinopathy.

\section{Discussion}

The Table summarizes the ocular findings in ten series of patients with systemic lupus erythematosus. When the data of the present study are compared with those of the nine earlier series, the low incidence of ocular findings in our series is striking. Retinal haemorrhages were reported in from 4.5 to 28 . I per cent. of patients in the other series; not one patient in the present study had a retinal haemorrhage. Cotton-wool spots were found in 5.5 per cent. of one series (Larson, I96I); in the others, the range was 9 to $28 \cdot 1$ per cent. In the present study, one cotton-wool spot was found in one eye of each of two patients (an incidence of 3.3 per cent.). Four series reported an incidence of oedema of the optic disc ranging from 2 to 3 per cent., and one reported an incidence of 13 per cent. (Spaeth, I967); no patient in our series demonstrated this finding. There is no mention of drusen or arterio-venous crossing changes by other authors. Hard exudates were reported in only two other series (Spaeth, I967; Harvey, Shulman, Tumulty, Conley, and Schoenrich, I954), in which incidences of 5 and 13 per cent. were found; the incidence was $1 \cdot 6$ per cent. in our series. Spaeth ( 1967 ) reported an 88 per cent. incidence of corneal staining, but this was seen in only 6.5 per cent. of the patients in our series.

There are several factors which may account for the differences between our findings and those of the other series. Our patients were all out-patients, most were being treated with steroids or antimalarials, and they were examined at times when their disease was in a period of relative remission. Previous studies included significant numbers of sick and hospitalized patients. For example, $5^{2}$ of the $1_{3} 8$ patients in the series of Harvey and others (1954) came to autopsy, as did 38 of 105 patients in the series of Tumulty (1954.) Of the 44 patients in the series of Jessar, Lamont-Havers, and Ragan (1953), 31 died, as did 135 of the 520 patients in the series of Dubois and Tuffanelli (1964). Seventeen patients in the series of Spaeth (1967) were examined during a period of disease activity. The description of lupus retinopathy given by Maumenee (1940) summarized the findings in five patients, all of whom died. Though the point has been made before (Brihaye-Van Geertruyden, Danis, and Toussaint, I954; Maumenee, I965), it is not generally emphasized that the retinopathy of lupus erythematosus is a phenomenon usually seen in more acutely ill patients. Brihaye-Van Geertruyden and others (1954) followed the course of fundus lesions in a patient with systemic lupus erythematosus. In observations over a Iomonth period, they found that the appearance and disappearance of retinopathy could be broadly correlated with the exacerbations and remissions of the systemic condition. Glifton and Greer (1955) described a patient with acute systemic lupus in whom extensive retinopathy was present 4 days before death, but whose fundi had been normal at the onset of the disease several months earlier. Keil (1940) stated that he frequently observed resolution of the fundus lesions as patients recovered from acute attacks and entered periods of remission. Similar variations in fundus findings were reported by Cluxton and Krause (I943) (cases I and 3). We have seen a few hospitalized systemic lupus patients; they were usually poorly controlled and often had severe retinopathy, but whether this was related to concomitant hypertension or to the lupus was unclear. 
Table Summary of the ocular findings in ten series of patients with systemic lupus erythematosus

\begin{tabular}{|c|c|c|c|c|c|c|c|c|}
\hline Authors & Date & $\begin{array}{l}\text { No. } \\
\text { of. } \\
\text { patients }\end{array}$ & $\begin{array}{l}\text { Conjunc- } \\
\text { tivitis }\end{array}$ & $\begin{array}{l}\text { Epi- } \\
\text { scleritis }\end{array}$ & $\begin{array}{l}\text { Corneal } \\
\text { stain }\end{array}$ & Uveitis & $\begin{array}{l}\text { Retinal } \\
\text { haemorrhages }\end{array}$ & $\begin{array}{l}\text { Cotton-wool } \\
\text { spots }\end{array}$ \\
\hline $\begin{array}{l}\text { Shearn and } \\
\text { Pirofsky }\end{array}$ & $195^{2}$ & $3^{2}$ & $\left(\begin{array}{l}5 \\
(156 \%)\end{array}\right.$ & & & & $\left(\begin{array}{l}9 \\
(28 \cdot 1 \%\end{array}\right)$ & $\left(\begin{array}{l}9 \\
(28 \cdot 1 \%\end{array}\right)$ \\
\hline $\begin{array}{l}\text { Jessar and } \\
\text { others }\end{array}$ & r953 & 44 & & & $\underset{(2 \cdot 3 \%)}{I}$ & & $\begin{array}{l}5 \\
(\mathrm{II} \cdot 4 \%)\end{array}$ & $\stackrel{6}{(13.6 \%)}$ \\
\hline $\begin{array}{l}\text { Harvey and } \\
\text { others }\end{array}$ & I954 & 105 & $\stackrel{5}{(4 \cdot 8 \%)}$ & $\stackrel{2}{(1 \cdot 9 \%)}$ & & & $\begin{array}{l}\text { II } \\
(10 \%)\end{array}$ & $\begin{array}{l}26 \\
(24 \%)\end{array}$ \\
\hline Haserick & 1954 & 275 & $(5 \%)$ & & & & $(5 \%)$ & $(9 \%)$ \\
\hline Tumulty & 1954 & 106 & & & & & & $(25 \%)$ \\
\hline $\begin{array}{l}\text { Armas-Cruz, } \\
\text { Harnecker, } \\
\text { Ducach, Jalil and } \\
\text { Gonzalez }\end{array}$ & I 958 & 66 & $\begin{array}{l}(20 \%) \\
\text { (of I08 } \\
\text { cases) }\end{array}$ & & & & $\stackrel{3}{(4 \cdot 6 \%)}$ & $(16 \cdot 6 \%)$ \\
\hline Larson & I 96 I & 200 & & $\stackrel{\mathbf{I}}{(\mathbf{0} \cdot 5 \%)}$ & & $\stackrel{\text { I }}{(0.5 \%)}$ & $\left(\begin{array}{l}9 \\
(4.5 \%)\end{array}\right.$ & $\begin{array}{l}\text { II } \\
(5 \cdot 5 \%)\end{array}$ \\
\hline $\begin{array}{l}\text { Dubois and } \\
\text { Tuffanelli }\end{array}$ & $\overline{1964}$ & 520 & $\overline{(10 \cdot 3 \%)}$ & & & $(0 \cdot 8 \%)$ & $(10.5 \%)$ & $(9 \cdot 6 \%)$ \\
\hline Spaeth & 1967 & 24 & $\stackrel{3}{(13 \%)}$ & $\stackrel{1}{(4 \%)}$ & $\begin{array}{l}21 \\
(88 \%)\end{array}$ & & $\stackrel{5}{(21 \%)}$ & $\stackrel{3}{(13 \%)}$ \\
\hline Present study & 1971 & $6 r$ & $\stackrel{2}{(3 \cdot 3 \%)}$ & o & $\left(\begin{array}{l}4 \\
(6 \cdot 6 \%)\end{array}\right.$ & $\left(\begin{array}{l}\mathrm{I} \\
(\mathrm{I} \cdot 6 \%)\end{array}\right.$ & o & $\stackrel{2}{(3 \cdot 3 \%)}$ \\
\hline $\begin{array}{l}\text { It should be } \\
\text { superficial retin } \\
\text { ing retina, are } \\
\text { can represent a } \\
\text { found in the a } \\
\text { Clifton and Gr } \\
\text { may bear some } \\
\text { was discussed in } \\
\text { produce a seve } \\
\text { and, using imn } \\
\text { localized in th } \\
\text { techniques hav } \\
\text { splenic and ren } \\
\text { Svec, Blair, anc } \\
\text { preparations of } \\
\text { I97o). It is qu } \\
\text { pathological pr }\end{array}$ & $\begin{array}{l}\text { stresse } \\
\text { al hac } \\
\text { not } \\
\text { n ind } \\
\text { bsenc } \\
\text { eer, It } \\
\text { relati } \\
\text { a rec } \\
\text { re vas } \\
\text { nunof } \\
\text { e wal } \\
\text { e der } \\
\text { al blo } \\
\text { d Kap } \\
\text { vessel } \\
\text { dite pc } \\
\text { ocesse }\end{array}$ & $\begin{array}{l}\mathrm{d} \text { that } \mathrm{t} \\
\text { morrha } \\
\text { necessar } \\
\text { ependen } \\
\text { of hyt } \\
55 \text {; Bae } \\
\text { onship t } \\
\text { ent pap } \\
\text { culitis ir } \\
\text { uoresce } \\
\text { s of ret } \\
\text { nonstrat } \\
\text { d vesse } \\
\text { lan, I } 96 \\
\text { in thes } \\
\text { ssible th } \\
\text {. }\end{array}$ & $\begin{array}{l}\text { fundus c } \\
\text { s, cotton } \\
\text { mere r } \\
\text { effect of } \\
\text { rtension } \\
\text { r, Klemp } \\
\text { the path } \\
\text { by Levir } \\
\text { rabbit ey } \\
\text { techniq } \\
\text { al vessel } \\
\text { of pe pr } \\
\text { of Antien } \\
\text { same org } \\
\text { t ocular }\end{array}$ & $\begin{array}{l}\text { langes ir } \\
\text { wool spo } \\
\text { flections } \\
\text { he disea } \\
\text { Larson, } \\
\text { rer, anc } \\
\text { genesis } \\
\text { e and h } \\
\text { es previc } \\
\text { les, they } \\
\text { and ve } \\
\text { esence o } \\
\text { with sy } \\
\text { uclear a } \\
\text { ns (Kris } \\
\text { lood ves }\end{array}$ & $\begin{array}{l}\text { systemi } \\
\text { ts, and o } \\
\text { of a co } \\
\text { e proces } \\
\text { I } 96 \mathrm{I} ; \mathrm{S} \\
\text { Schifrin } \\
\mathrm{f} \text { the ret } \\
\text { ard ( } \mathrm{I} 97 \\
\text { usly sens } \\
\text { found } \\
\text { ssels in } \\
\text { gamm } \\
\text { temic lu } \\
\text { tibodies } \\
\text { inan anc } \\
\text { els may }\end{array}$ & $\begin{array}{l}\text { lupus ery } \\
\text { dema of } \\
\text { comitant } \\
\text { in ocula } \\
\text { aeth, I } 96 \\
\text { i935). } \\
\text { opathy o } \\
\text { ized to } \\
\text { tinuclear } \\
\text { e optic } \\
\text { globulin } \\
\text { us (Vazq } \\
\text { nave bee } \\
\text { Kaplan, } \\
\text { e involve }\end{array}$ & $\begin{array}{l}\text { thematosus, } \\
\text { he disc and } \\
\text { hypertensi } \\
\text { tissues, an } \\
7 \text {; Maume } \\
\text { A phenome } \\
\text { f lupus eryt } \\
\text { workers w } \\
\text { ovine serun } \\
\text { antibody } \\
\text { nerve head } \\
\text { and comp } \\
\text { uez and Di } \\
\text { eluted fro } \\
\text { I967; Svec } \\
\text { d in similar }\end{array}$ & $\begin{array}{l}\text { primarily } \\
\text { surround- } \\
\text { n. They } \\
\text { they are } \\
\text { ee, I } 940 \text {; } \\
\text { lon which } \\
\text { lematosus } \\
\text { re able to } \\
\text { albumin } \\
\text { complexes } \\
\text { Similar } \\
\text { ement in } \\
\text { on, I } 957 \text {; } \\
\text { n isolated } \\
\text { nd Allen, } \\
\text { immuno- }\end{array}$ \\
\hline
\end{tabular}




\begin{tabular}{|c|c|c|c|c|c|}
\hline$m s$ & $\begin{array}{l}\text { Arterio- } \\
\text { venous } \\
\text { crossing } \\
\text { changes }\end{array}$ & $\begin{array}{l}\text { Arteriolar } \\
\text { narrowing }\end{array}$ & $\begin{array}{l}\text { Retinal } \\
\text { oedema }\end{array}$ & Papilloedema & Additional findings \\
\hline & & & & $\frac{1}{(3 \cdot I) \%}$ & Subconjunctival haemorrhage $-2(6 \cdot 2 \%)$ \\
\hline & & & $(2 \cdot 3 \%)$ & & Vasculitis with irregular beading-I $(2 \cdot 3 \%)$ \\
\hline & & & & $\begin{array}{l}2 \\
(\mathrm{r} \cdot 9 \%)\end{array}$ & $\begin{array}{l}\text { CRV occlusion-2 }(1 \cdot 9 \%) \\
\text { Retinal haemorrhages with blindness-1 ( } 1 \%)\end{array}$ \\
\hline & & & 8 & $2(3.0 \%)$ & Hyperaemia of disc and dilated and dark veins $-9(13.6 \%)$ \\
\hline & & & & $\begin{array}{l}5 \\
(2 \cdot 5 \%)\end{array}$ & $\begin{array}{l}\text { CRV occlusion-I }(0 \cdot 5 \%) \\
\text { Optic atrophy-I (o.5\%) } \\
\text { Retinal scarring-1 (0.5\%) } \\
\text { Perforating scleral ulcer-1 (0.5\%) }\end{array}$ \\
\hline & & $(13.2 \%)$ & & & $\begin{array}{l}\text { Diplopia_l } 1 \% \\
\text { Keratoconjunctivitis sicca } 1 \cdot 4 \%\end{array}$ \\
\hline & & $(21 \%)$ & & $(13 \%)$ & $\begin{array}{l}\text { Blepharitis-1 }(4 \%) \\
\text { Retinal chloroquine changes-2 }(8 \%) \\
\text { Optic disc drusen-1 }(4 \%) \\
\text { Retinal venous engorgement-2 }(8 \%) \\
\text { Retinal atrophy-2 }(8 \%)\end{array}$ \\
\hline & $(\mathrm{n}+5 \%)$ & $\begin{array}{l}\mathrm{I} 3 \\
(2 \mathrm{I} \cdot 3 \%)\end{array}$ & o & o & $\begin{array}{l}\text { Blepharitis-1 }(\mathrm{I} \cdot 6 \%) \\
\text { Macular pigmentary mottling-32 }(52 \cdot 5 \%) \\
\text { Crater hole of optic disc-1 }(\mathrm{I} \cdot 6 \%) \\
\text { Drusen-13 }(2 \mathrm{I} \cdot 3 \%)\end{array}$ \\
\hline
\end{tabular}

\section{Summary}

(1) The ocular findings in 6 I out-patients with systemic lupus erythematosus examined over the last decade are reported.

(2) The results of previous series on the subject are summarized.

(3) The incidence of lupus retinopathy in the present series is lower than that reported elsewhere, reflecting the fact that today's lupus patients are more likely to have their disease controlled for longer periods of time.

(4) The relationship of fundus lesions to the activity of the systemic disease is discussed.

(5) The existence of retinal changes in systemic lupus erythematosus in the absence of hypertension is emphasized.

We should like to thank Dr. Naomi Rothfield for her cooperation in this study, and Mrs. Doris Ortega for secretarial assistance.

\section{References}

armas-gruz, R., harnecker, J., ducach g., Jalil, J., and gonzalez, f. (1958) Amer. F. Med., 25, 409 
baehr, G., klemperer, P., and schifrin, A. (1935) Trans. Ass. Amer. Physcns, 50, 139 BRIHAYe-VAN GeERTRUYden, M., DANis, P., and toussaint, c. (1954) Arch. Ophthal. (Chicago), 5I, 799 Clifton, F., and GReER, C. H. (1955) Brit. F. Ophthal., 39, I Gluxton, H. E., and Krause, L. A. M. (1943) Ann. intern. Med., 19, 843 DUBois, e. L., and tuffanelli, D. L. (1964) J. Amer. med. Ass., 190, 104 haRVey, A. McG., ShUlman, L. E., TUMUlty, P. A., CONLEY, G. L., and SGhoenRigh, E. H. (I954) Medicine (Baltimore), 33, $29 \mathrm{I}$ HASERICK, J. R. (1954) "Lupus Erythematosus", p. 135. McGraw-Hill, New York JeSSAR, R. A., Lamont-haVers, R. W., and ragan, c. (1953) Ann. intern. Med., 38, 71 7 KEIL, H. (1940) Arch. intern. Med., 66, 339 KRISHNAN, C., and KAPLAN, м. н. (1967) 7 . clin. Invest., 46, 569 LARson, D. L. (196I) "Systemic Lupus Erythematosus". Little Brown, Boston; Churchill, London LEVINE, R. A., and WARD, P. A. (1970) Amer. F. Ophthal., 69, I023 MAUMENEE, A. E. (1940) Ibid., 23, 97 I - (1965) Arch. Ophthal. (Chicago), 56, 557 SHEARN, M. A., and PIROFSKy, B. (1952) Arch. intern. Med., 90, 790 SPAETH, G. L. (1967) New Engl. F. Med., 276, i 68 SVEC, K. H., and ALlEN, S. T. (1970) Science, 170, 550 - , Blair, J. D., and KAPLAN, м. н. (1967) 7. clin. Invest., 46, $55^{8}$ tumulty, P. A. (1954) F. Amer. med. Ass., 156, 947 vazQuez, J. J., and DIXoN, F. J. (1957) Lab. Invest., 6, 205 